\title{
Prediction of preeclampsia by a combination of maternal spot urinary protein-creatinine ratio and uterine artery doppler
}

\author{
Rupali Modak ${ }^{1}$, Amitrajit Pal ${ }^{2 *}$, Amitava Pal ${ }^{3}$, Mrinal K. Ghosh ${ }^{4}$
}

\begin{abstract}
${ }^{1}$ Department of Obstetrics and Gynecology, R.G. Kar Medical College, Kolkata, West Bengal, India
${ }^{2}$ Department of Pharmacology, Grant Medical College, Mumbai, Maharashtra, India

${ }^{3}$ Department of Obstetrics and Gynecology, Burdwan Medical College, Purba Barddhaman, West Bengal, India

${ }^{4}$ Department of Radio Diagnosis, Burdwan Medical College, Purba Barddhaman, West Bengal, India
\end{abstract}

Received: 21 November 2019

Accepted: 30 December 2019

\section{*Correspondence:}

Dr. Amitrajit Pal,

E-mail: amitava.628@rediffmail.com

Copyright: (c) the author(s), publisher and licensee Medip Academy. This is an open-access article distributed under the terms of the Creative Commons Attribution Non-Commercial License, which permits unrestricted non-commercial use, distribution, and reproduction in any medium, provided the original work is properly cited.

\begin{abstract}
Background: Preeclampsia (PE) is heterogeneous disorder. The aim of the study was to observe the role of a spot urinary protein - creatinine ratio (UPCR) and uterine artery doppler velocimetry measured between 20-24 weeks of gestation in prediction of preeclampsia.

Methods: Prospective observational study conducted on 120 pregnant mothers with singleton pregnancy between 20 24 weeks of gestational age in two tertiary teaching hospitals in eastern India. A spot urinary protein creatinine ratio (UPCR) was determined in a mid- stream urine sample and estimation of protein was done by immunoturbidimetric micro albumin method and creatinine by modified Jaffe's method. Doppler velocimetry was also determined at 20-24 weeks of gestation. A notch in uterine artery, unilateral or bilateral; or RI $>0.7$ and PI of $>1.45$ were considered to have an abnormal result. Women were followed-up and relationship between variables was assessed by Chi- square test.

Results: Women who subsequently developed preeclampsia had significantly higher UPCR (median $44.8 \mathrm{mg} / \mathrm{mmol}$ ) when compared with women of unaffected groups (median $26.6 \mathrm{mg} / \mathrm{mmol}$ ). The optimum spot urinary UPCR to predict preeclampsia was $35.5 \mathrm{mg} / \mathrm{mmol}$ and the cut-off value $>35.5 \mathrm{mg} / \mathrm{mmol}$ had a test sensitivity $(80 \%)$, specificity (94.06\%), PPV (66.76\%) and NPV (96.94\%). The area under curve (AUC) of spot UPCR in ROC curve was 0.949 (95\% CI,0.891 - 1.000). For predicting preeclampsia, the mean uterine artery RI had to be $>0.7$ having sensitivity (60\%), specificity $(97.03 \%)$, PPV (75\%) and NPV (94.23\%). The area under curve (AUC) was 0.856 (95\% CI, 0.742 - 0.971).

Conclusions: Second trimester UA doppler is a useful screening test for prediction of preeclampsia. This test works best when combined with a spot UPCR and accuracy of both the methods for prediction of preeclampsia was $92.24 \%$.
\end{abstract}

Keywords: Pre-eclampsia, Prediction, Urinary protein-creatinine ratio, Uterine artery doppler

\section{INTRODUCTION}

Preeclampsia (PE) is heterogeneous disorder. Preeclampsia complicates $5-10 \%$ of all pregnancies world-wide and are associated with significant maternal morbidity and mortality. ${ }^{1,2}$ Preeclampsia is diagnosed when the blood pressure is at or above $140 / 90 \mathrm{mmHg}$ occurring on two occasions at least 6 hours apart, associated with proteinuria greater than $300 \mathrm{mg} / 24$ hours after 20 weeks of gestation. ${ }^{3}$ The pathophysiological events resulting preeclampsia begin early in pregnancy and precede the onset of clinical features. ${ }^{4}$ One of the 
early pathophysiological hall marks is the endothelial damage. ${ }^{5,6}$ Microalbuminuria is a marker of endothelial dysfunction. The established gold standard for the diagnosis of proteinuria is the 24 hours urine collection. However, the urine protein creatinine ratio (UPCR) is a single sample test, wherein the result is available within 2 hours and is eight times less expensive than the 24-hour urine protein test. ${ }^{7}$

The fundamental cause of preeclampsia is thought to be the abnormal uteroplacental circulation resulting from failure of second wave of trophoblastic invasion into spiral arterioles. This will result in increased resistance to flow within the uterine arteries and decreased placental perfusion. This concept has lead to the idea of using Doppler assessment of uterine artery flow velocity wave form as a screening test for predicting preeclampsia. UA Doppler sonography done during second trimester can predict preeclampsia. ${ }^{8}$ Doppler indices like resistance Index (RI) and pulsatility index (PI) are considered as indirect measurement of utero-placental circulation. Abnormal uterine artery doppler flow velocimetry is defined as a mean PI more than 1.45 or/and the presence of bilateral diastolic notches. ${ }^{9}$

So, the aim of the study is to evaluate the efficacy of UPCR and uterine artery doppler measured in early mid trimester of pregnancy for prediction of subsequent development of preeclampsia and to compare the accuracy of both these methods.

\section{METHODS}

A prospective observational study conducted between January 2018 to June 2019 in the department of obstetrics and gynecology, Burdwan Medical College, Burdwan and R G Kar Medical College, Kolkata, West Bengal, India.

With regard to the prevalence of preeclampsia in the area $(\mathrm{p}=0.08)$ and according to the formula $\mathrm{n}=\mathrm{r} 2 * \mathrm{p}(1-$ $\mathrm{p}) / \mathrm{m}^{2}$ [ $\mathrm{n}=$ required sample size, $\mathrm{r}=$ confidence level at 95\% (standard deviation of 1.96), $\mathrm{m}=$ margins of error at $5 \%$ (std. value of 0.05$)]$; so $\mathrm{n}=(1.96) 2 * 0.08(1-0.08) /$ (0.05) $2 ; \mathrm{n}=113$.

A total of 120 pregnant women after assessment of exclusion and inclusion criteria were selected at random by random number generation table at 20-24 weeks of gestation attending antenatal clinics of the hospitals and followed up till delivery. Inclusion criteria included singleton pregnancy, second trimester (20-24 weeks) of pregnancy and age between 18 and 40 years. Multiple pregnancies, chronic hypertension and other chronic diseases like CKD, hypothyroidism, diabetes, fetal anomalies and fetal death were excluded from the study. Out of 120 patients only 4 cases did not turn-up and finally 116 pregnant mothers were selected in the study.
All selected candidates after informed consent and ethical clearance were screened for a spot urinary protein creatinine ratio and uterine artery doppler at the time of enrolment and were followed up till delivery by history, clinical examination and by measuring blood pressure in sitting posture to detect preeclampsia. Comparison was made between unaffected group (Group 1) and preeclampsia (Group 2) by spot PCR and uterine artery doppler.

Spot midstream urine was collected for estimation of protein by immunoturbidimetric micro albumin method and creatinine by modified Jaffe's method in ERBA semiautomatic biochemistry analyzer with commercially available reagent. Data was expressed as urine protein $(\mathrm{mg} / \mathrm{dl}) /$ urine creatinine $(\mathrm{g} / \mathrm{dl})=$ UPCR in $\mathrm{mg} / \mathrm{g}$ or $\mathrm{mg} / \mathrm{mmol}$ multiplying by 0.113 . The cut-off value of PCR was taken as $35.5 \mathrm{mg} / \mathrm{mmol}$ in the present study. Those with UPCR ratio equal to or more than $35.5 \mathrm{mg} / \mathrm{mmol}$ were considered as test positive and the ratio less than $35.5 \mathrm{mg} / \mathrm{mmol}$ was considered as test negative.

Transabdominal uterine artery (UA) doppler was done by using curvilinear probe $(3.5 \mathrm{MHz})$ in Philips HD6 ultrasound machine by localizing uterine artery at uterocervical junction where it appears to cross the external iliac artery with an insonation angle of < 30-degree, velocity $>60 \mathrm{~cm} / \mathrm{sec}$ the variables analyzed were:

Resistance index (RI) was calculated by using formula: $\mathrm{RI}=$ peak systolic velocity - peak diastolic velocity/ peak systolic velocity. The cut-off value of RI was $>0.7$ in the present study

Pulsatility index (PI) will be calculated using formula: PI $=$ peak systolic velocity End diastolic velocity / Mean velocity. The cut-off value of PI was > 1.45 in the present study.

An early diastolic notch was defined as a V-shaped deflection towards the base line in early diastole. Abnormal uterine artery doppler flow velocimetry is defined as a mean PI more than 1.45 or/and the presence of unilateral or bilateral diastolic notches or /and elevated resistance index $(\mathrm{RI})>0.7$.

All these women were followed up periodically till delivery and during each follow up visit blood pressure, weight measurement, urinary protein analysis was performed to evaluate the development of any signs and symptoms of severe preeclampsia like, nausea, vomiting, epigastric pain, visual disturbances, decreased urine output. In those patients who developed pre-eclampsia, severity and gestational age of development of the disease were noted.

\section{Statistical analysis}

All the relevant data were analyzed by appropriate statistical tests using statistical package for social science 
(SPSS) version 20.0. Continuous variables were expressed as mean, median standard deviation (SD) and compared across the group using Mann-Whitney U test. Categorical variables were expressed as number of patients and percentage and compared across the group using Fisher exact test. The performance of the screening tests were evaluated by sensitivity, specificity, positive predictor value (PPV), negative predictor value (NPV) and ROC curve. An alpha level of $5 \%$ had been taken, if p-value was less than 0.05, it was considered as significant.

\section{RESULTS}

Women who subsequently developed preeclampsia had higher spot UPCR (mean $\pm \mathrm{SD}, 44.12 \pm 9.43 \mathrm{mg} / \mathrm{mmol})$ in comparison to unaffected group (mean $\pm \mathrm{SD}, 26.84 \pm 4.69$ $\mathrm{mg} / \mathrm{mmol}$ ) and the difference was statistically significant $(\mathrm{p}=0.001)$. Women who developed preeclampsia had significantly higher mean uterine artery doppler resistance index (RI) and pulsatility index (PI) of $0.71 \pm 0.2$ and $1.1 \pm 0.24$ respectively $(\mathrm{p}=0.001)$ (Table 1$)$.

Table 1: Distribution of urinary protein creatinine ratio (UPCR) and different uterine artery doppler indices.

\begin{tabular}{|llllllll|}
\hline Parameters & $\begin{array}{l}\text { Unaffected (Group 1) } \\
\text { Mean }\end{array}$ & $\begin{array}{l}(\mathbf{n}=101) \\
\text { SD }\end{array}$ & $\begin{array}{l}\text { 95\% CI of } \\
\text { mean }\end{array}$ & $\begin{array}{l}\text { Preeclampsia (Group 2) }(\mathbf{n}=15) \\
\text { Mean } \\
\text { (median) }\end{array}$ & $\begin{array}{l}\text { SD } \\
\text { 95\% CI of }\end{array}$ & $\begin{array}{l}\text { 95\% Can } \\
\text { mean }\end{array}$ \\
\hline Spot UPCR (mg/mmol) & $26.84(26.6)$ & 4.69 & $25.91-27.77$ & $44.12(44.8)$ & 9.43 & $38.71-48.53$ & 0.001 \\
\hline UA doppler RI & $0.46(0.46)$ & 0.1 & $0.44-0.48$ & $0.71(0.76)$ & 0.2 & $0.59-0.83$ & 0.001 \\
\hline PI & $0.88(0.84)$ & 0.19 & $0.82-0.92$ & $1.1(1.02)$ & 0.34 & $0.91-1.30$ & 0.001 \\
\hline
\end{tabular}

UA: uterine artery, RI: resistance index, PI: Pulsatility index, CI: confidence interval

Table 2: Association of RI, PI and diastolic notch of UA with preeclampsia.

\begin{tabular}{|lllll|}
\hline UA doppler components & $\begin{array}{l}\text { Unaffected } \\
\text { Group } 1)(\mathbf{n}=\mathbf{1 0 1})\end{array}$ & $\begin{array}{l}\text { Preeclampsia } \\
(\text { Group } 2)(\mathbf{n}=\mathbf{1 5})\end{array}$ & $\begin{array}{l}\text { Total } \\
(\mathbf{n}=\mathbf{1 1 6})\end{array}$ \\
\hline \multirow{2}{*}{ RI } & $\leq 0.7$ & $98(84.48)$ & $6(5.17)$ & $104(89.65)$ \\
\hline \multirow{2}{*}{ PI } & $>0.7$ & $3(2.59)$ & $9(7.76)$ & $12(10.35)$ \\
\hline \multirow{2}{*}{ Diastolic notch } & $\leq 1.4$ & $99(85.34)$ & $12(10.35)$ & $111(95.69)$ \\
\cline { 2 - 5 } & $>1.4$ & $2(1.73)$ & $3(2.58)$ & $5(4.31)$ \\
\cline { 2 - 5 } & Absent & $101(87.07)$ & $14(12.07)$ & $115(99.14)$ \\
\hline
\end{tabular}

RI: resistance index, PI: Pulsatility index, $\mathrm{n}(\%)$.

Table 3: Association of uterine artery doppler and spot UPCR with onset of preeclampsia.

\begin{tabular}{|c|c|c|c|c|c|}
\hline Preeclampsia & Parameters & $\begin{array}{l}\text { Early }(<34 \text { weeks }) \\
(n=2)\end{array}$ & $\begin{array}{l}\text { Late }(>34 \text { weeks }) \\
(n=13)\end{array}$ & $\begin{array}{l}\text { Total } \\
(n=15)\end{array}$ & p-value \\
\hline \multirow{2}{*}{ UA doppler } & Abnormal & $2(13.33)$ & $9(60)$ & $11(73.33)$ & \multirow{2}{*}{0.524} \\
\hline & Normal & $0(0)$ & $4(26.67)$ & $4(26.67)$ & \\
\hline \multirow{2}{*}{$\begin{array}{l}\text { Spot UPCR } \\
(\mathrm{mg} / \mathrm{mmol})\end{array}$} & $\geq 35.5$ (normal) & $2(13.33)$ & $10(67.67)$ & $12(80)$ & \multirow{2}{*}{0.629} \\
\hline & $\leq 35.5$ (abnormal) & $0(0)$ & $3(20.00)$ & $3(20)$ & \\
\hline
\end{tabular}

UA doppler velocimetry showed increased RI (cut-off value $>0.7)$ in 12 women $(10.35 \%)$ and among them 9 $(7.76 \%)$ developed preeclampsia. Six women developed PE subsequently in normal RI subjects. Out of $5(4.31 \%)$ subjects of increased PI (cut-off values > 1.4), 3 individuals developed preeclampsia in later part of pregnancy and 12 subjects (10.35\%) developed PE in normal PI values. Out of total 15 preeclamptic mothers only one (0.86) had diastolic notch and remaining 14 $(12.07 \%)$ showed no notch in diastolic component (Table 2).

Table 3 depicts that in case of abnormal UA doppler, majority $(60 \%)$ of the mothers developed preeclampsia after 34 weeks of gestation and only $13.33 \%$ developed PE before 34 weeks., whereas no mothers developed PE in less than 34 weeks in case of normal doppler velocimetry $(\mathrm{p}=0.524)$ Majority of UPCR positive patients $(67.67 \%)$ having cut-off value of $\geq 35.5$ $\mathrm{mg} / \mathrm{mmol}$ developed preeclampsia after 34 weeks, whereas $20 \%$ developed late PE ( $\geq 34$ weeks) in spot UPCR negative $(\leq 35.5 \mathrm{mg} / \mathrm{mmol})$ pregnant women.

Out of total 18 UPCR positive women, 12 women developed preeclampsia; whereas among total UPCR negative 98 women, only three developed the disease, but in whom the test is negative. For preeclampsia screening, spot UPCR (cut off $\geq 35.5 \mathrm{mg} / \mathrm{mmol}$ ) had sensitivity of 
$80 \%$, specificity of $94.06 \%$, PPV of $66.67 \%$ and NPV of $96.94 \%$. Out of sixteen abnormal uterine artery doppler (RI > 0.7/PI > 1.4/diastolic notch present) 11 patients developed PE subsequently and five patients had only false positive tests i.e. tests are positive but who do not have the disease; whereas 4 patients developed PE in later months of pregnancy among hundred normal uterine artery doppler. For preeclampsia screening, uterine artery Doppler having more RI, PI and diastolic notch had sensitivity of $73.33 \%$, specificity of $95.05 \%$, PPV of $68.75 \%$ and NPV of $96 \%$. Accuracy of both the spot UPCR and uterine artery doppler (including all the parameters of PI, RI and diastolic notch) for prediction of preeclampsia was same and it was $92.24 \%$ (Table 4).

Table 4: Performance of UPCR and UA doppler in prediction of preeclampsia.

\begin{tabular}{|llllllllll|}
\hline Findings & TP & TN & FP & FN & $\begin{array}{l}\text { Sensitivity } \\
(\%)\end{array}$ & $\begin{array}{l}\text { Specificity } \\
(\%)\end{array}$ & $\begin{array}{l}\text { PPV } \\
(\%)\end{array}$ & $\begin{array}{l}\text { NPV } \\
(\%)\end{array}$ & $\begin{array}{l}\text { Predictive } \\
\text { accuracy }(\%)\end{array}$ \\
\hline Spot UPCR (mg/mol) & 12 & 95 & 6 & 3 & 80 & 94.06 & 66.67 & 96.94 & 92.24 \\
\hline UA doppler index, RI & 9 & 98 & 3 & 6 & 60 & 97.00 & 75 & 94.23 & 92.24 \\
\hline UA doppler index, PI & 3 & 99 & 2 & 12 & 20 & 98.02 & 60 & 89.19 & 87.93 \\
\hline UA doppler diastolic notch & 1 & 101 & 0 & 14 & 6.67 & 100 & 100 & 87.83 & 87.93 \\
\hline $\begin{array}{l}\text { UA doppler, (RI > 0.7/PI }> \\
\text { 1.4/presence of diastolic notch) }\end{array}$ & 11 & 96 & 5 & 4 & 73.33 & 95.05 & 68.75 & 96 & 92.24 \\
\hline
\end{tabular}

Table 5: AUC of spot PCR and uterine artery doppler indices.

\begin{tabular}{|lllll|}
\hline Test result variable(s) & \multirow{2}{*}{ AUC } & p-value & \multicolumn{2}{l|}{ Asymptotic (95\% confidence interval) } \\
\hline Spot UPCR (mg/mol) & & Lower bound & Upper bound \\
\hline Uterine artery doppler index RI & 0.949 & $<0.001$ & 0.891 & 1.000 \\
\hline Uterine artery doppler index PI & 0.776 & $<0.001$ & 0.742 & 0.971 \\
\hline
\end{tabular}

Figure 1 and Table 5 summarize the optimum spot UPCR to predict preeclampsia (cut- off value $\geq 35.5 \mathrm{mg} / \mathrm{mmol}$ ) had a test sensitivity of $80 \%$, specificity of $94.06 \%$. The area under the curve (AUC) was 0.949 (95\% CI 0.891 $1.000 ; \mathrm{p}<.0 .001)$. The AUC of uterine artery doppler indices RI and PI having cut-off values of 0.7 and 1.4 were 0.856 (95\% CI $0.742-0.971 ; \mathrm{p}<0.001)$ and 0.776 (95\% CI 0.665-0.887; $\mathrm{p}=0.001)$ respectively.

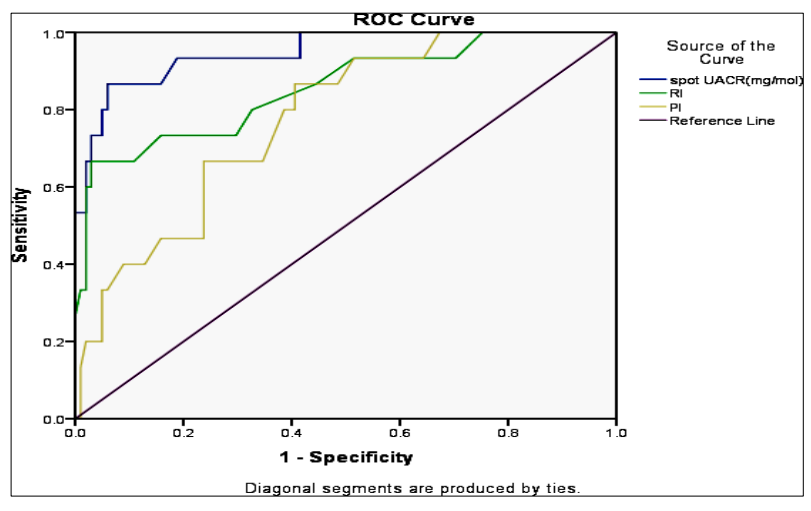

Figure 1: ROC curve of spot UPCR and uterine artery doppler (PI, RI) for prediction of preeclampsia.

\section{DISCUSSION}

Prediction of preeclampsia (PE) can be very helpful in preventing the disorder or in decreasing its severity. It has thus a major focus of research in PE but expected progress could not be achieved due to lack of understanding of the pathophysiology of the disease. ${ }^{10}$ Addition of patients' characteristics like BMI or blood pressure improved the identification of women at risk for preeclampsia. In our study spot urinary UPCR at 20-24 weeks was significantly higher in women who subsequently developed preeclampsia with mean value of $44.12 \pm 9.43 \mathrm{mg} / \mathrm{mmol}$ than in those who remain unaffected with mean value of $26.84 \pm 4.69 \mathrm{mg} / \mathrm{mmol}$. Baweja et al, and Fatema et al, found the similar results. ${ }^{11,12}$ The sensitivity of spot UPCR at the cut-off value of $\geq 35.5 \mathrm{mg} / \mathrm{mmol}$ as a screening test to predict preeclampsia in our study was found to be $80 \%$ which is comparable to the studies done by Baweja et al, (83.3\%), Fatema et al, $(80 \%)$ and Mishra et al, $(87.5 \%) .{ }^{11-13}$ In the present study abnormal uterine artery doppler indices (RI $>$.0.7/PI > 1.4/ presence of diastolic notch) were associated with increased risk of developing preeclampsia in later part of pregnancy. The cut-off value of RI and PI was similar with the study of Sahoo et al. ${ }^{14}$ Razieh DF et al, found that 23 pregnancies $(85.2 \%)$ with preeclampsia had RI more than 0.7 and only $4(14.8 \%)$ had RI $<0.7$ (p $=0.001){ }^{8}$ Our study showed that out of 15 preeclamptic pregnant mothers, 9 pregnancies $(7.76 \%)$ had only RI $>$ 0.7 and 6 of them $(5.17 \%)$ had RI $<0.7$ (p $<0.001)$. The sensitivity, specificity of the present study is more or less similar with different studies. ${ }^{14-16}$ Results of our study show that mid trimester or second trimester uterine artery doppler indices like PI and RI can be useful tools in predicting preeclampsia. When PI index is used alone the sensitivity was less in comparison to RI (20\% versus 
$60 \%)$. So, RI in second trimester is more sensitive in predicting preeclampsia than PI alone, but combined RI, PI and notching gives better results. The high NPV (96\%) of uterine artery doppler of the present study corroborates well with other studies but Barati et al, found high PPV $(88.2 \%)$ in contrast to our study $(68.75 \%)$ owing to large number of sample size. ${ }^{14-16}$ The relative risk (RR) of developing preeclampsia with abnormal uterine artery doppler study in our groups was very high 17.19 (95\% CI, 0.23 to 47.49) when compared to the study of Bhattacharyya et al (RR, 5.427; 95\% CI, 2.272-12.958). ${ }^{17}$

In clinical practice no single marker can effectively predict the risk of preeclampsia. The current trend is to test a combination of biochemical markers in first and second trimester. Improved prediction of preeclampsia has been noticed when serum markers are combined with uterine artery doppler indices.

\section{CONCLUSION}

The present study concludes that a single spot UPCR in early mid trimester of pregnancy in asymptomatic pregnant women is a reliable screening test for prediction of development of preeclampsia in later months of gestation. This test works better when combined with uterine artery doppler. The abnormal UA doppler indices (RI, PI and diastolic notch) between 20-24 weeks can accurately identify women at risk of development of preeclampsia in contrast to normal UA doppler velocimetry. The current study also showed that the predictive accuracy of both spot UPCR and uterine artery doppler was same (92.24\%). However, the study was done in a small group of women, and so further study in a large cohort is necessary to validate the reliable study outcome.

Funding: No funding sources

Conflict of interest: None declared

Ethical approval: The study was approved by the Institutional Ethics Committee

\section{REFERENCES}

1. Martin JA, Hamilton BE, Sutton PD, Ventura SJ, Mathews TJ, Osterman MJ. The prevalence of preeclampsia in our study is $12.93 \%$ which is comparable to the incidence of 4 $18 \%$ in developing countries. Births: final data for 2008. Natl Vital Stat Rep. 2010;59(1):3-71.

2. Khan KS, Wojdyla D, Say L, Gulmezoglu AM, Van Look PF. WHO analysis of causes of maternal death: a systematic review. Lancet. 2006;367:1066-74.

3. Mak A, Cheung MW, Cheak AA, Ho RC. Combination of heparin and aspirin is superior to aspirin alone in enhancing live births in patients with recurrent pregnancy loss and positive anti-phospholipid antibodies: a metaanalysis of randomized controlled trials and meta regression. Rheumatol. 2011;49:281-8.
4. Levine RJ, Lam C, Qian C, Yu KF, Maynard SE, Sachs $\mathrm{BP}$, et al. Soluble endoglin and other circulating anti angiogenic factors in preeclampsia. $\mathrm{N}$ Engl $\mathrm{J}$ Med. 2006;355:992-1005.

5. Young BC, Levine RJ, Karumanchi SA. Pathogenesis of preeclampsia. Annu Rev Pathol. 2010;5:173-92.

6. Khan F, Belch JJ, Macleod M, Mires G. Change in endothelial function precedes the clinical disease in women in whom preeclampsia develops. Hyper. 2005;46:1123-8.

7. Robert M, Sepandj F, Liston RM, Dooley KC. Random protein creatinine ratio for the quantification of proteinuria in pregnancy. J Obstet Gynecol.1997;90:893-5.

8. Razieh D, Mahdyeh M, Saedeh A, Reza NM. Uterine artery doppler sonography in predicting preeclampsia and IUGR at 14-16-week gestation. World Applied Scien. 2013;22(2):197-201.

9. Toal M, Keating S, Machin G, Dodd J, Adamson SL, Windrim RC, et al. Determinants of adverse perinatal outcome in high risk women with abnormal uterine artery doppler images. Am J Obstet Gynecol. 2008; 19:330.e1330-e7.

10. Kozer E, Costei AM, Boskovie R, Nulman I, Nifkar S, Koren G. Effects of aspirin consuming during pregnancy on pregnancy outcomes: meta-analysis. Birth Defects Res Part B Dev Reprod Toxicol. 2013;68(1):70-84.

11. Baweja S, Kent A, Masterson R, Roberts S, McMahon LP. Prediction of preeclampsia in early pregnancy by estimating the spot urinary albumin: creatinine ratio using high performance liquid chromatography. BJOG. 2011;118(9):1126-32.

12. Fatema K, Khatun M, Akter S, Ali L. Role of urinary albumin in the prediction of preeclampsia. Faridpur Med Coll J. 2011;6(1):14-8.

13. Mishra VV, Goyal PA, Priyankur R, Choudhary S, Aggarwal RS, Gandhi K, et al. Evaluation of spot urinary albumin - creatinine ratio as screening tool in prediction of preeclampsia in early pregnancy. J Obstet Gynecol India. 2017;67(6):405-8.

14. Sahoo K, Saha P, Bhairagond S, Raj RV. The role of uterine artery doppler sonography in predicting preeclampsia at 14-20 weeks of gestation. Int J Sci Res. 2016;5:37-47.

15. Barati M, Shahbazian N, Ahmadi L, Masihi S. Diagnostic evaluation of uterine artery doppler sonography for the prediction of adverse pregnancy outcomes. J Res Med Sci. 2014;19(6):515-9.

16. Konchak PS, Bernstein IM, Capeless EL, Uterine artery doppler velocimetry in the detection of adverse outcomes in women with unexplained elevated maternal serum alpha-fetoprotein levels. Am J Obstet Gynecol.1995; 173:1115-9.

17. Bhattacharrya SK, Kundu S, Kabiraj SP. Prediction of preeclampsia by midtrimester uterine artery Doppler velocimetry in high-risk or low risk- women. J Obstet Gynecol India. 2012;62(3);297-300.

Cite this article as: Modak R, Pal A, Pal A, Ghosh MK. Prediction of preeclampsia by a combination of maternal spot urinary protein-creatinine ratio and uterine artery doppler. Int J Reprod Contracept Obstet Gynecol 2020;9:635-9. 